\title{
FACEBOOK ASA TOOL FOR MANAGING RELATIONS BETWEEN UNIVERSITIESAND STUDENTS IN POLAND AND LITHUANIA. FINDINGS OF PILOT STUDIES
}

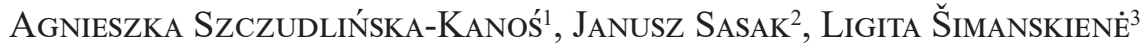 \\ Jagiellonian University (Poland), Klaipėda University (Lithuania)
}

\begin{abstract}
Nowadays, in times of socio-economic and especially information technology development, the issue of human relations becomes more and more important. The aim of the article was to analyse the role of social media in shaping relations between universities and students. Given that aim the authors carried out research where in the framework of international cooperation prepared a research tool and conducted pilot studies. Students of selected universities, including Polish and Lithuanian ones, were a target group of the study. The conducted research clearly indicated the dominant role of Facebook as a communication portal used by students within universities. It appeared to be the most recognised primary tool for both rapid information flow and relationship building. The findings may be of interest to universities and public institutions or private actors, and, in particular, to social network operators.

KEYWORDS: managing relations, universities, students, Facebook.
\end{abstract}

\section{JEL CODES: M15.}

\section{Introduction}

The rapid increase in the number of corporations that was observed in the 1980s has led to new ways in improving productivity and quality. The term "contact management" came into being, which involved creating of customer information databases and collecting of their contacts. Initially, the concept of contact management focused primarily on marketing and mass communication without personalisation. In every organization exchange of information happens daily, it is transmitted in direct and indirect ways, a never stopping communication process is in progress in which participates every single member of the organization (Guščinskiene, 2000: 79). Communication is the exchange of information between two or more participants, emotional state interaction, relationships that satisfy human and organizational needs (Misevičius, 2007).

Another decade brought software development and the World Wide Web. New technological capabilities enabled development of the rational relationship management system. Organizations started to think of the complex, two-way relationships with their clients and ways of gaining feedback from them. The following years forced another change. There was a need for closer and more functional contact with customers

Agnieszka Szczudlińska-Kanoś - dr., assoc. prof. at the Institute of Public Affairs of the Jagiellonian University, Poland

Scientific interests: social policy, local self-government and public management

E- mail: agnieszka.szczudlinska-kanos@uj.edu.pl

2 Janusz Sasak - dr., assoc. prof. at the Institute of Public Affairs of the Jagiellonian University, Poland Scientific interests: IT management systems, process management

E-mail: janusz.sasak@uj.edu.pl

3 Ligita Šimanskiene - prof. dr. at the Department of Management of Klaipeda University, Lithuani.

Scientific interests: organizational cultures, relationship, leadership

E-mail: ligita.simanskiene@gmail.com 
and business partners. Consequently, appeared features such as a separate campaign management system, customer satisfaction analysis, sales management and promotions. The combination of all these tasks in one system - Customer Relationship Management (CRM) - allowed for easier management and public relations (Goldenberg, 2003; Rojala, 2003).

Already in the 1980 s, creation of quality management systems made companies to automate sales processes and handle complaints. The proper management of these processes seeked to bind the customer to the company by making sure that he or she would also choose products and services offered by the company in the future. The combination of these areas has resulted in the creation of a CRM - the management concept that has quickly evolved and is currently focused around three areas: customer behaviour analysis, business process automation and customer communication.

Problem. Despite the extensive literature on the subject, there is still no one universal definition of relationship management, yet nowadays methods and tools of relationship management are applied in all sectors of the economy. Globalisation processes, broad access to information and improved language skills among young people mean that higher education institutions should offer not only high level education but also a management model that could establish and maintain proper relationships with students. Taking into account the principles of higher education financing, and pervasive demographic tendencies, it becomes necessary to search for new ways in attracting and retaining the best students, thus relationship management tools may prove to be one of the most important instruments to ensure proper functioning of higher education institutions (Drapińska, 2011). The social media stimulate new discussions in different areas and it is usually used by the younger generation (Auškalnienè, 2012). Social networks help to believe individuals that using these networks makes them equal because of the same background and interest they share. People in social networks invest their knowledge and resources (Sander, Sloka, 2016). Social network sites are online tools to exchange information and to create a profile to present themselves to large audience (Sander, Sloka, Paužuolienė, 2015). People having experience with social networks know what to expect and they would not use this network if they could not trust the tool.

The aim of the article is to analyse the role of social media in the processes of shaping relations between universities and students.

Research methods: analysis, synthesis, quantitative research.

In the study the authors assessed relationship management tools used at higher education institutions in Poland and Lithuania. In the studies, which were permanently conducted from May 2016 to March 2017, there were 580 students studying at 9 universities, including Lithuania, Poland, Romania, and Portugal. For the purposes of this article, the results of questionnaires received only from Polish and Lithuanian students were analysed (300 questionnaires received from Poland and 120 from Lithuania).

\section{Managing relationships in theoretical terms}

At present, CRM is often simplified and considered only in the context of transactional computer systems used to establish and maintain business relationships. Relationship management is understood as a business strategy of building relationships and managing clients to optimize long-term benefits. CRM is not only an IT tool, but the overall philosophy of every organization.

Some research shows that younger respondents, 18-25 years old, feel the need to be online on social networks, because it means constantly being with their friends (Siudikienè, 2014: 54). The newest technologies and ability to use them by respondents is associated with activeness and higher social position. The use of e-study systems is an advantage not only because it cuts back on expenditure of studying energy, problems of time and space, but it also is teaching oriented at the student (Stonkiene, 2014: 60). Even though there is quite a lot of studying programs like that in Lithuania, they need to be further developed and new ones should be created. How leisure time is spent shows not only the values and virtues of the person, but also person's opportunities and resources (Siudikienè, 2013: 39). Lifestyle changes with professional skills, the higher position persons operate in, the less leisure time they have, and that time is often used for professional 
improvement. The use of media usually does not change on the weekends or during the week. D. Janavičiene and M. Sinušaitè (2011) suppose that by using informational services and interpersonal communication in electronical space makes work more enjoyable, workers don't feel that much tension and pressure, it became a natural way of answering questions of the customers, it provides more time to think how to answer their requests and etc. But it had been noticed that more problems are had by clients. And computer literacy of employees should be one of the main goals.

Due to the fact that nowadays consumers tend to be more aware of their needs, it is necessary to develop strategies to maintain individual relationships with all clients. So we are dealing with the conscious management of customers and their service to build a loyal group of regular customers by satisfying their individual needs and preferences and satisfying their expectations (Łobos, Pypłacz, 2005).

Universities are organizations in which stakeholders share specific relationships. When analysing the history of universities and their ideas, it should be noted that these are the specific organizations in which it is assumed that all stakeholders (students, employees, founders and owners) form a community. Missions and visions of the modern university also point to the special importance of community and unity between all the groups making up the university. On the other hand, publications in the field of management science (both public and private) are treated like all service organizations with typical business relationships. The student is referred to as the customer, and the university as service provider.

Taking into account the specificity of the learning process, the relationship between students and the university must not be restricted to typical business relationships, as the process of providing educational services is always linked to the particular link between the provider and the recipient. This connection facilitates the process of knowledge exchange, accelerates learning, and facilitates enduring effects. The research shows that the lack of a specific agreement between the teacher and the student leads to low effectiveness of the learning process and the rapid loss of knowledge transferred. This particularity of functioning of universities is well reflected in the fact that a few dozen years ago the advertising of public services in Poland was perceived as an indelicacy due to the relationship between student and lecturer and the specificity of knowledge based on authority, charisma, trust and mutual respect (Sowa, 2009). As S. Jastiuiginas (2011: 9) stated, information security goal is to ensure confidentiality, integrity and availability of information. It is noted that management of universities should pay close attention on how to prevent digital piracy (Akulavčius, 2015).

The introduction of university the management methods taken directly from the business and the change of forms of funding irreversibly changed the relationship between the university and the students. Current trust and informal relationships have been replaced by formal contracts with each student individually. This change is noticeable in relationships at various levels, both between the university as an institution and the students as well as in the student-student relationship and the student-lecturer relationship. Among the many opinions about these changes are predominantly negative, indicating that the community disappears, the level of education decreases, and the quality of studies and the level of knowledge of graduates drastically decreases. As a remedy, it is often proposed to restore historically conditioned relationships, to increase trust and to tighten relationships so that all parties to the didactic process feel equal members of the community. Thus the relationship management of universities cannot be guided by purely marketing principles (Piróg, 2014).

Relationship management is usually considered in two main areas - social relations (communal relationship) and the relationship involving the exchange (exchange relationship) (Yang, Alessandri, Kinsey, 2008). From the perspective of universities, both types of relationships are very important and should not be separated. It is impossible to share knowledge effectively without referring to or neglecting social relationships. Analysing the relationship with the university student, we can use the classification proposed by A. Marszałek (2009), in which the author distinguished four approaches: to student as customer, product, partner or co-creator. The approach to the student as a client is characterized by actions aimed at convincing potential candidates to choose the university and the direction of studies, and after completing them offer complementary products (second, third or postgraduate studies). In this concept, attention is paid to purely business relationships, and the customer gets the desired product and service. Remember that it is not always a fair education, and in many cases the desired result is a diploma rather than a knowledge. Approaching a 
student as a product impersonates a student. It is treated as a material from which the university (lecturer, didactic process) creates a unit equipped with knowledge in accordance with market requirements or accepted by the university standards.

As noted by A. G. Raišienè and S. Jonušauskas (2013) technostress is caused and work efficiency is decreased not necessarily by the use of informational technologies, but human actions while using it for work. That means that work has to be planned, and a schedule of work and rest had to be followed.

In the partnership approach, the student has an opportunity to influence the course of the educational process, co-create study programs and select the content of education. The process of participation is now formalized and usually comes down to selecting parts of subjects from the list proposed by the university. There was a departure from the university tradition in which the lecturer was a conductor, and the student consciously made the choice of the area of knowledge. This change is the result of the standardization and evaluation of the transferred knowledge and the level of teaching. The fourth type of approach assumes that every student should be treated in an individual way - from the start of their studies to their completion. It is assumed that the student consciously chooses the university, then creates the process of acquiring knowledge, actively participating in the selection of content and forms of education. As a result, each student receives an individual and unique knowledge resource. This situation can be compared to individual teaching, in which the student actively participates in both the selection of content, their order, and the establishment of forms of knowledge transfer. This approach assumes that each person has his or her own hierarchy of needs and the learning process should be tailored to it. The diversity of approaches requires the development of an effective (for the university and student) relationship management model in higher education. W. Wereda (2009) shows that the model of relationship management in higher education depends on the following factors: relational factors; resource factors; competence factors; internal marketing factors, information technology factors, social policy, historical conditions, market offer.

The studies do not clearly indicate which of these factors are crucial to building relationships. This state of affairs is consistent with the interpretative paradigm in which the understanding of a relationship, and therefore its evaluation, is made individually and subjectively by each participant. M. Kostera (1996) emphasizes that the world of social life (and thus the relationships) there is no "outside" of our mind, waiting that his rights have been discovered, but all the time is created by ourselves. Thus, it should be recognized that relationships are a specific set of interdependencies and evaluations of a situation that exists under strictly defined conditions. Changing any element or even the passage of time changes the perception of the world and the relationships that connect individuals. Traditionally, relationships, their development, maintenance, and finally termination were usually associated with personal physical or written contact of the parties. The personal relationship that is most influenced by the way the information is communicated is most strongly influenced by relationships in the classical model. In the course of personal contacts, the information is transmitted over multi-channel. The official verbal channel is complemented by non-verbal information, indicating the importance and meaning of the messages and the motivations of the parties. This form of communication is also important in the process of transferring knowledge. According to the research, if the non-verbal communication is available in the transfer of knowledge, and the parties share positive feelings, the process is more effective and the knowledge transferred is better remembered. Social change, especially the introduction of new communication technologies, has made relations and their maintenance change. In the generation of current students, the primary means of communication is the Internet, in particular social networking sites, instant messaging, web pages and e-mail. Initially after the Internet was launched, the primary tool for supporting the relationship was e-mail and its mailing groups. For instant communication, instant messengers were used to send text messages, and presently both audio and video. Developing and implementing the concept of web 2.0 has opened up new opportunities for establishing and maintaining relationships. Originally, this tool was designed from the co-creation of Internet services by Internet users. On the basis of web 2.0 tools there developed concept and built social networking sites. The development of Internet access technology and the popularization of social networking sites have made the users of this service virtually accessible through the active part of the day to access information published on social 
networking sites. As researchers note, this leads to loosening of physical ties, impoverishment of forms of communication, shortening of messages and lowering the quality of relationships. This process is particularly affecting people up to the age of 30 , with the upper limit constantly shifting, which is related to the passage of time and the learning of new technologies by people of higher age ranges.

Taking into consideration the fact that students are mostly people under the age of 30 , and therefore commonly used for information technology, it is advisable to focus on electronic tools of relationship shaping and above all on social networks.

\section{Assessment of social networking sites as a tool for shaping a student-university relationship. Results of pilot studies conducted in Poland and Lithuania}

In the age of fast-growing electronic media, the current traditional methods of establishing and shaping relationships are ineffective and it is imperative to seek solutions that will ensure not only fast flow but also ensure that the parties of the relationship are in constant contact. Social networking sites, which guarantee these features of the communication process, have in recent years become the primary tools shaping relationships both in the private and public spheres. Understanding their specificities and mechanisms of shaping and maintaining relationships through social networks can reduce costs and increase the quality of relationships between organizations and their stakeholders.

The purpose of the study was to analyse the role of social media, especially Facebook, in the processes of shaping relations between universities and students. The study involved 580 students studying at 9 universities, including Lithuania, Poland, Portugal and Romania. By leveraging the potential of the research network, it has become possible to reach respondents from different countries and to obtain research results in a short space of time. The average time from informing the respondents by network members to get the first test results is about 12 hours. Information about the study was disseminated both through official partner sites and by fan-page. Definitely faster and more efficient carrier (more respondents' responses) turned out to be college fan-page. The use of an electronic research tool has significantly reduced the costs of both preparation, carrying out and analysis of research results.

The analysis of the research material clearly shows that information about universities, about the direction of the program, students receive mainly the internet channels - official website university, web browsers, or social networking sites. It is clear from the analysis of the research that information about colleges and universities is mainly obtained from online channels - official websites, web browsers or social networks less often than friends (Chart 1). The content on the official web site serves primarily to convey formal information related to the functioning of the university. The official websites of the institutes are mainly treated as bulletin boards. Group profiles usually perform the following roles:

- the group integrator - contains information about meetings, events;

- knowledge repository - includes notes, supplementary materials, studies, complementary e-learning platform;

- fast communication channel in situations where it is necessary to notify the whole group in a short time.

According to the policies pursued by the universities under the study, and consultation on tasks and projects, and transfer of works, e-learning platforms are designed.

By determining the popularity of social networking sites, data analysis shows that in both Lithuania and Poland the most popular are Facebook (respectively $100 \%$ and $95 \%$ of users) and Instagram (55\% and 31\%) (Figure 2).

The research shows that students in Lithuania spend more time on social networking (Figure 3). More than $50 \%$ of Lithuanian students responded that they spent several hours at the portals, or they log in the morning and are available for the evening. Just three percent of Lithuanians replied that their activity was less than an hour per day, whereas $20 \%$ of Polish students indicated such the answer. However, the same percentage has indicated that there are no rules when it comes to social networking. 


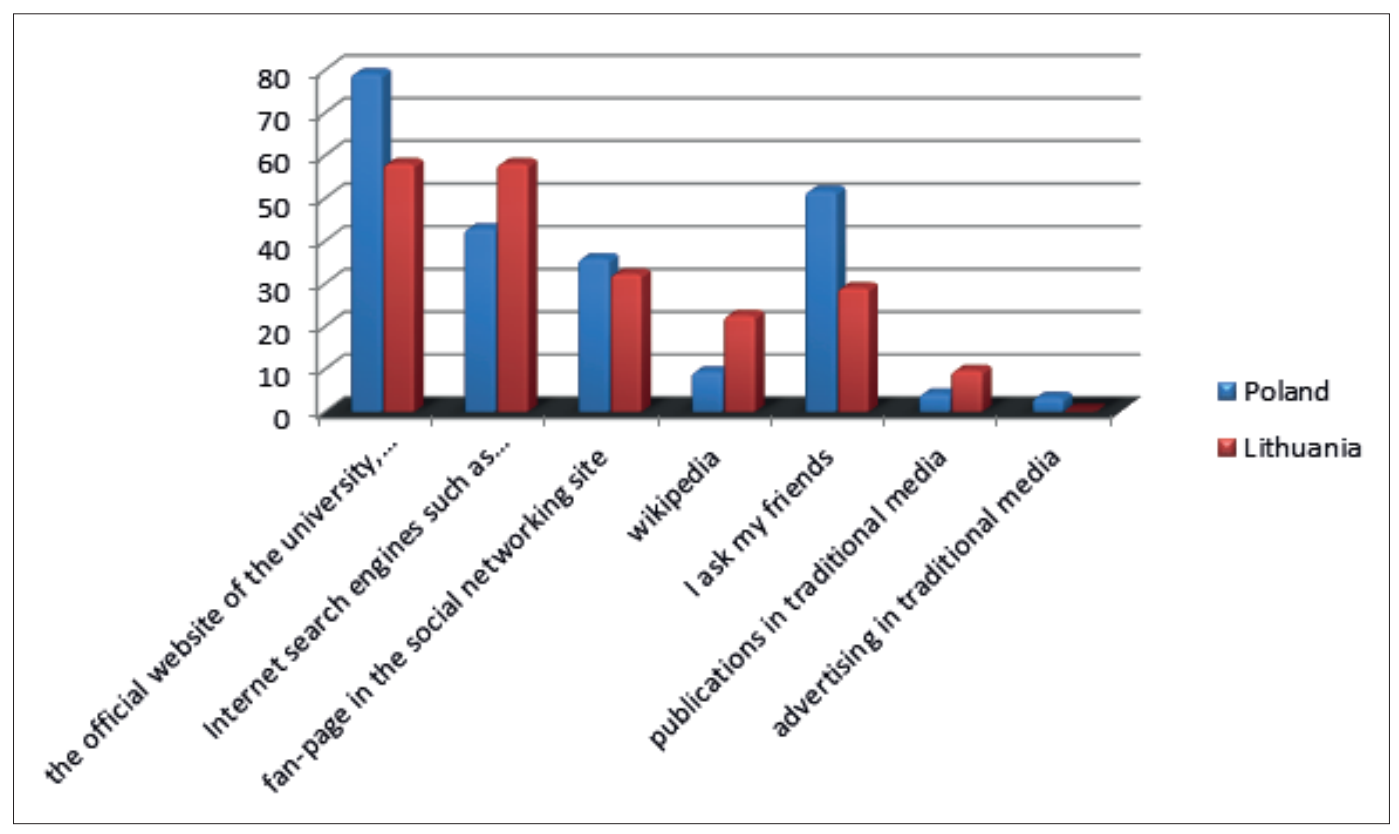

Figure 1. The way for searching information about the university or classes

Source: the authors' elaboration.

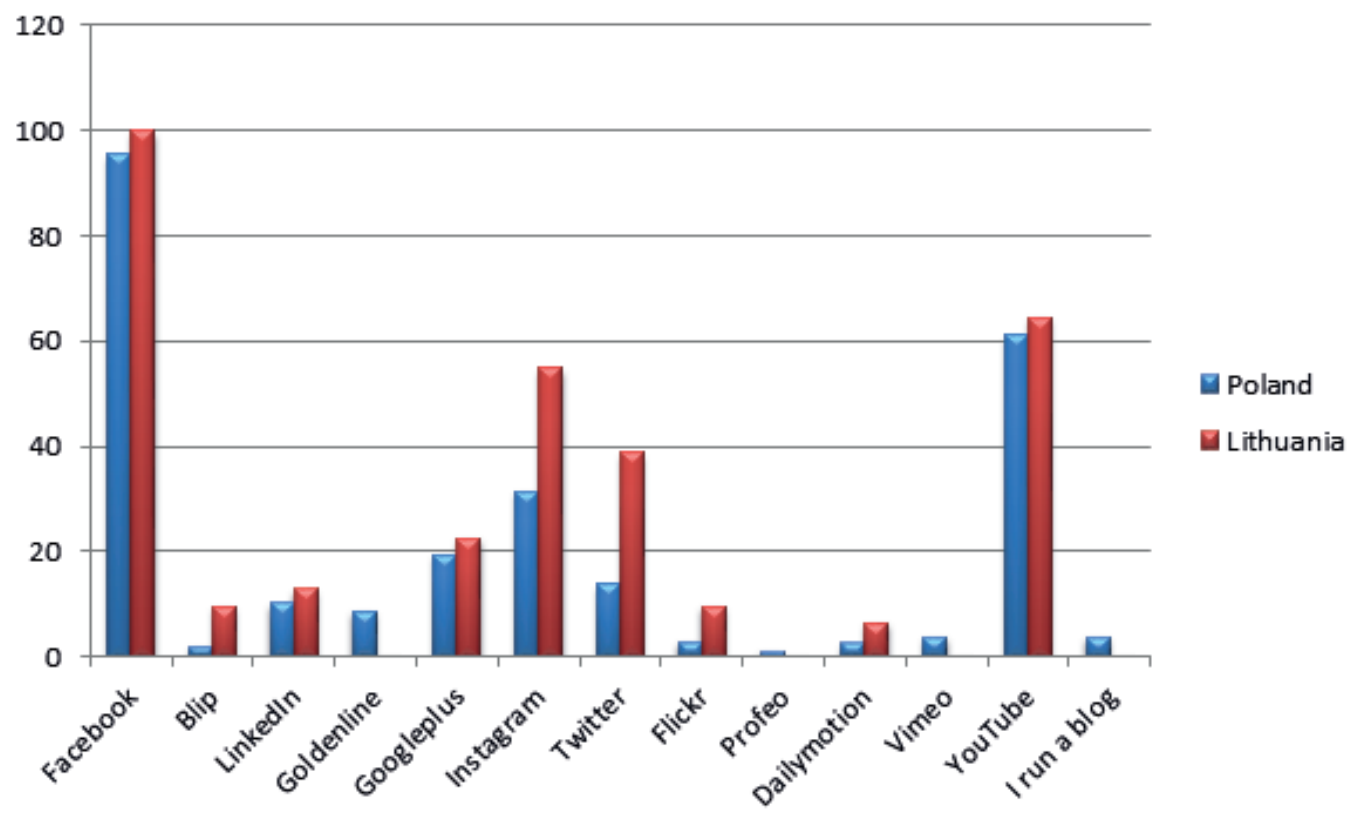

Figure 2. Accountability of social portals

Source: the authors' elaboration.

Students are rather positive about their relationship with the universities they study. Yet $30 \%$ students from Poland and only 19\% from Lithuania considered them neutral. The lack of relations with the university indicated respectively $20 \%$ and $13 \%$ of students. 


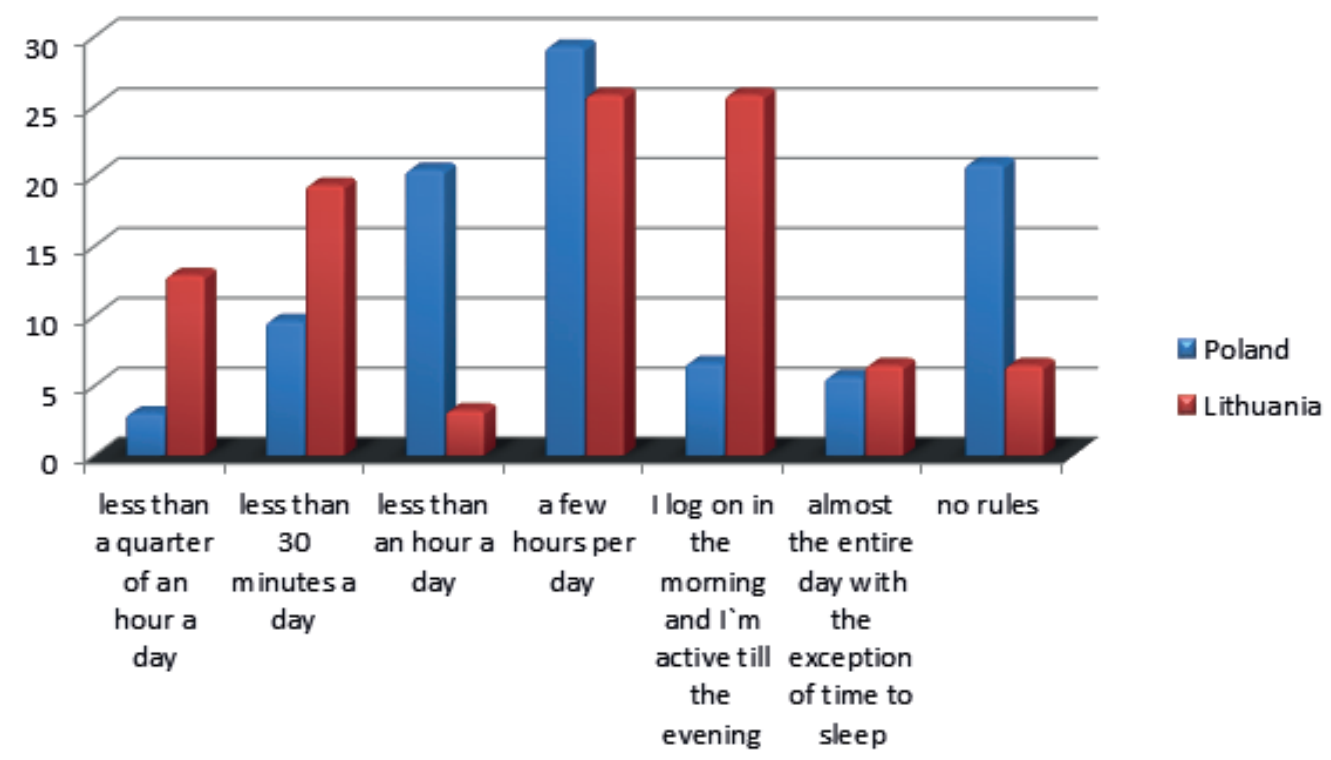

Figure 3. Time devoted to the use of social networking sites

Source: the authors' elaboration.

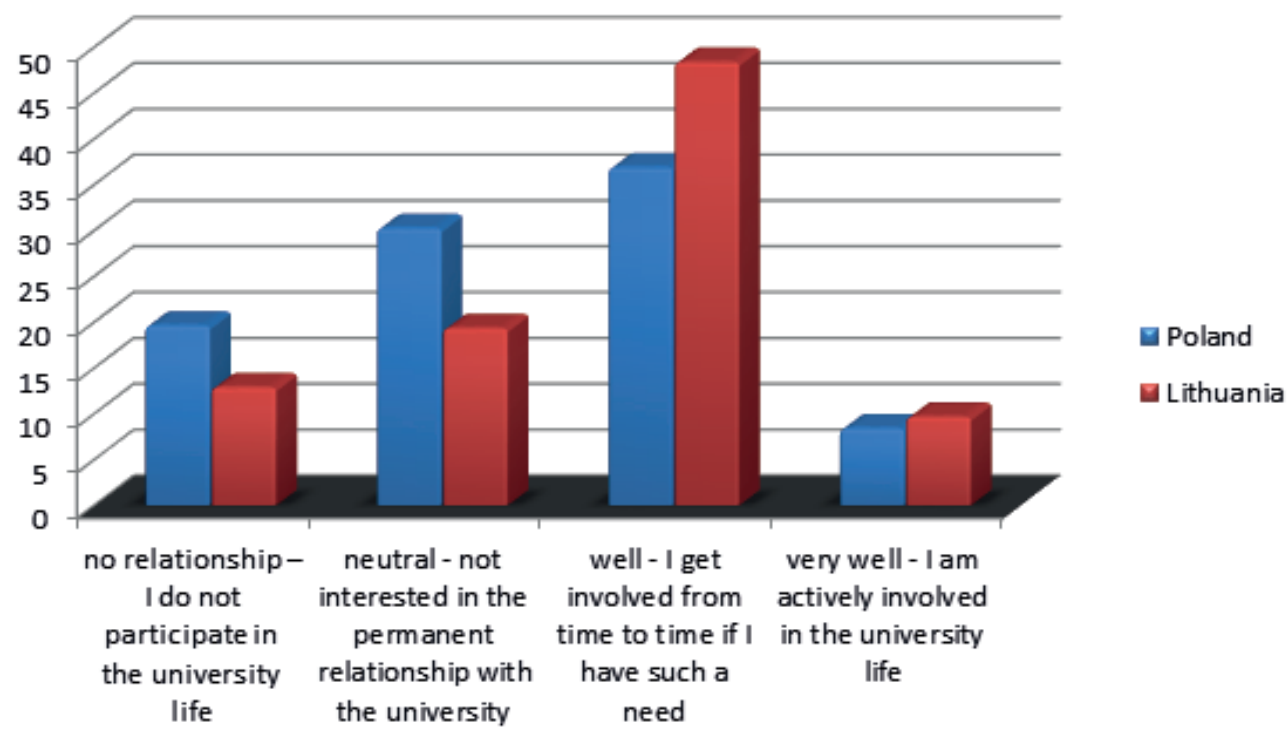

Figure 4. Estimation of relationships with the university

Source: the authors' elaboration.

Analysis of student impact on the university life and teaching has shown that $24 \%$ of students from Poland and $32 \%$ from Lithuania has the opportunity to contact teachers even after classes. In addition, $22 \%$ respectively and $16 \%$ students have the opportunity to express themselves about the quality of the course through teacher assessment. The above results are surprising because in all studied universities students had the opportunity to contact lecturers after the end of classes, for example, in consultations, and also had the opportunity to evaluate the courses. 


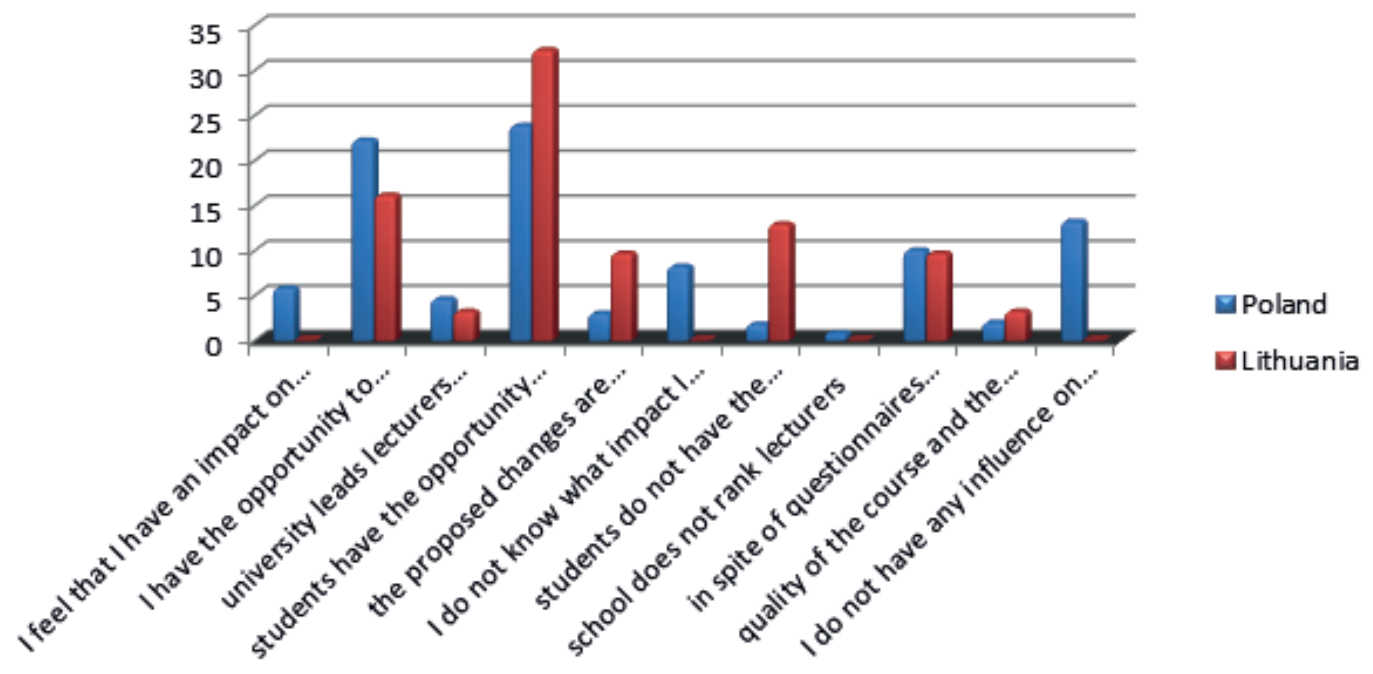

Figure 5. The level of your impact on the university life and the way the teaching is done

Source: the authors' elaboration.

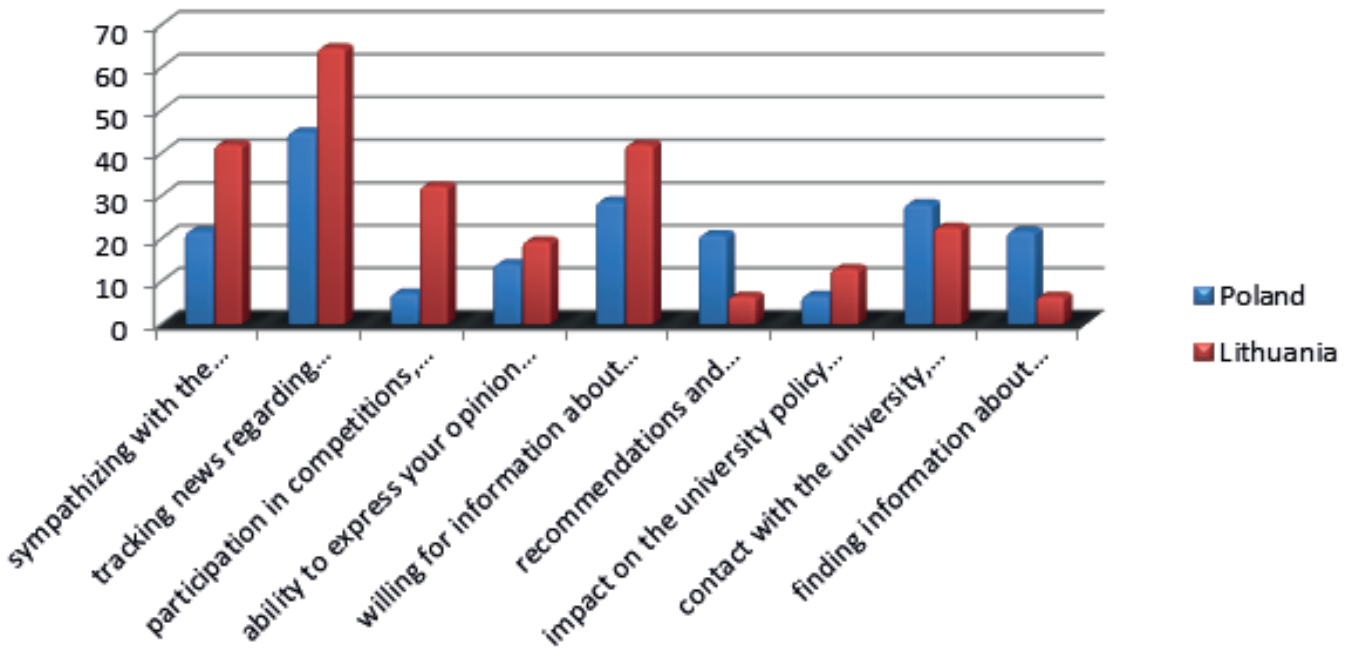

Figure 6. A fan of the university page in social networking sites

Source: the authors' elaboration.

The reasons to remain a fan-page on social networking university were varied. For a large percentage of students (65\% in Lithuania, $45 \%$ in Poland) the incentive was to follow news, knowledge, information and university attachment $-41.9 \%$ and $21.6 \%$ respectively. Relatively few students cared about possibilities to influence the university policy by creating strategies for the coming years $(12.9 \%$ and $6.6 \%)$.

The surveyed students noticed a number of benefits that enabled them to remain at the university's networking sites, mainly on Facebook. For $87 \%$ of Lithuanian students it was especially valuable contacting with teaching staff, approaching the academic community (38\%), drawing on the ideas and knowledge of other students (35\%). For Polish students it was important to maintain contact with other students and the academic community (44.5\%) and to use other people's knowledge and ideas (37.5\%). 


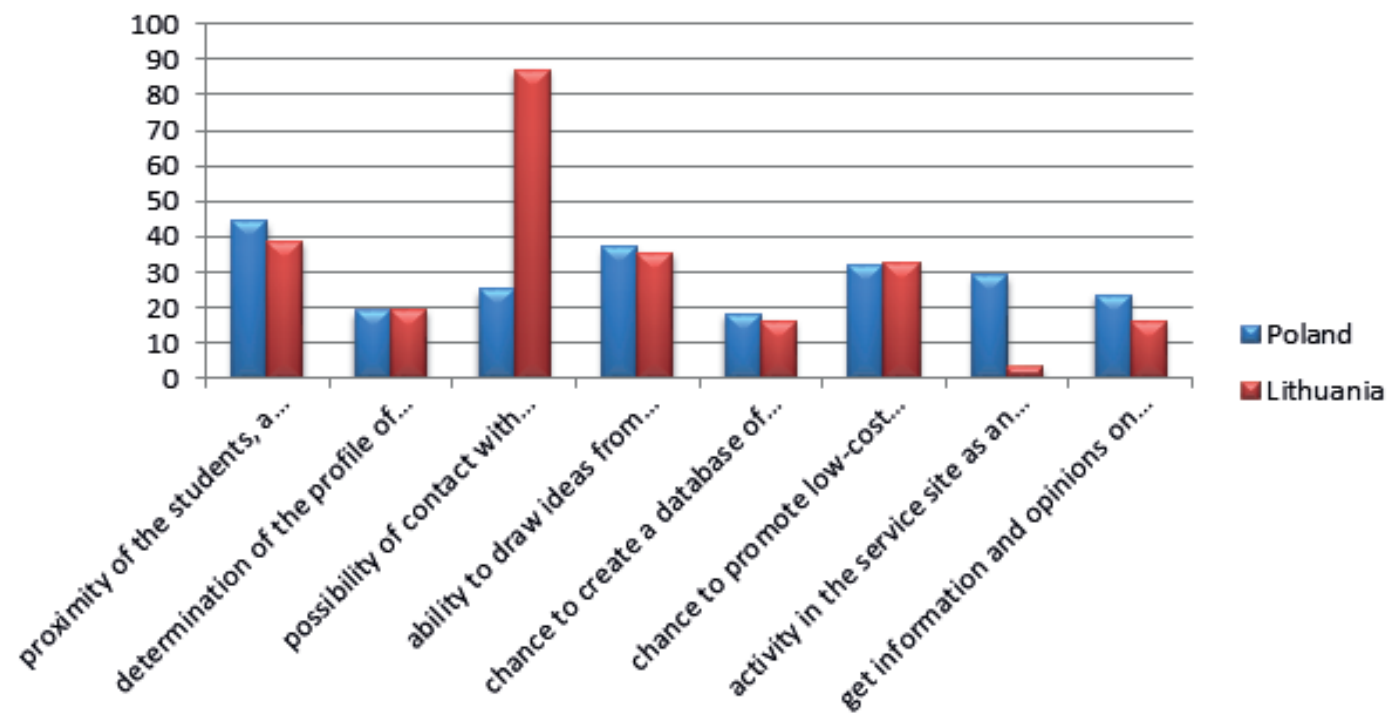

Figure 7. The benefits for the university resulting from its presence on social networking sites

Source: the authors' elaboration.

\section{Conclusions}

Permanently developing information societies change methods and channels of communication and force these changes both on private companies and public organizations, including universities. Therefore, traditional physical contact channels of information transmission are replaced by newer electronic channels introduced in the market. This communication change is the unavoidable and indisputable phenomenon. Thus organizations have to listen to their expectations and needs to meet the demands of ever-more demanding customers. This difficult task also lies on colleges and universities, which in order to ensure high quality of services should maintain proper relations with students listening to their needs.

Nowadays, proper functioning of the university requires internet activity based on an official website and a social networking profile. The research revealed that students in Poland and Lithuania mostly use Facebook: 95\% of students from Poland and all Lithuanian students pointed out Facebook as a primary communication portal. Facebook is regarded as the most widely used primary tool for both rapid flow of information and for building relationships. However, the rest of the surveyed social networking sites are usually informative. The information posted on these sites is treated as a supplement to the main communication channel, i.e., Facebook. Therefore, this supplementary information is usually limited to additional images, media files, or short messages that initiate a problem or point to a problem.

Thus higher education institutions when managing relationships should take into account social changes and the widespread use of electronic information channels. On the other hand, students' expectations should be met in line with the university tradition, where personal contact with students is particularly important. Giving priority solely to electronic tools in shaping relationships makes students slow down and consequently relax. Rigid retention of traditional communication channels or inappropriate social networking slows down processes and can lead to a sense of superfluity of activities resulting in dissatisfaction and deterioration of relationships.

When designing a relationship management system, proportions of using classical and modern tools must be evaluated and balanced. There are well known attempts to create virtual universities where physical contacts are limited to the bare minimum, however, studies reveal that relationships in such organizations are very relaxed and unstable. Therefore, universities need to modify methods and tools used to manage 
relations, taking into account modern realities, in particular progressing globalisation processes and the free flow of information and people. Yet this process cannot be realised in isolation from didactic and scientific processes carried out in universities. Thus it is necessary to analyse students' needs, individualise the approach, and involve all members of the academic community in the process of creating and maintaining relationships. Relational management cannot be a one-time operation, aimed at quickly achieving long-term effects. The process of creating and developing relationships is a time-consuming process, the effects of which are visible in the long-term future.

\section{References}

Akulavičius, M. (2015). Skaitmeninio piratavimo valdymas kūrybinio turinio industrijoje. Kaunas: VU KHF. Daktaro disertacija.

Auškalnienè, L. (2012). Assessing Participation Online: Youth and their Involvement in Social Media. Informacijos mokslai, No. 59, p. 105-116. Vilniaus universitetas.

Drapińska, A. (2011). Zarzadzanie relacjami na rynku ustug edukacyjnych szkót wyższych. PWN, Warszawa.

Goldenberg, B. J. (2003). CRM Automation. New York: Prentice Hall.

Guščinskienė, J. (2000). Organizaciju sociologija. Kaunas: Technologija.

Janavičienè, D., Sinušaitè, M. (2011) Tarpasmeninès komunikacijos su klientais ypatumai teikiant elektronines paslaugas bibliotekose. Informacijos mokslai, Nr. 58, p. 94-109. Vilniaus universitetas.

Jastiuginas, S. (2011). Informacijos saugumo valdymas Lietuvos viešajame sektoriuje. Informacijos mokslai, Nr. 57, p. $7-25$.

Kostera, M. (1996). Postmodernizm w zarzadzaniu. Wydawnictwo PWE, Warszawa.

Łobos, K., Pypłacz, P. (2005). Funkcje i narzędzia zarządzania dla matych i średnich przedsiębiorstw. Warszawa.

Marszałek, A. (2009). Zarządzanie relacjami na rynku usług edukacyjnych. Marketing i Rynek, No. 4, p. 15-19.

Misevičius, V. (2007). Verslo etikos ir bendravimo organizavimo pagrindai. Kaunas: Technologija.

Piróg, D. (2014). Konkurowanie uniwersytetów na rynku usług edukacyjnych.w warunkach kryzysu gospodarczego $i$ nasilających się trudności tranzycji absolwentów. Prace Komisji Geografii Przemysłu Polskiego Towarzystwa Geograficznego, UP Kraków, No. 28, p. 115-128.

Raišienè, A. G., Jonušauskas, S. (2013). Informacinių ir komunikacinių technologijų įtaka darbuotojų technostresui: situacijos Lietuvoje charakteristika. Informacijos mokslai, Nr. 66, p. 78-95. Vilniaus universitetas.

Rajola, F. (2003). Customer Relationship Management: Organizational and Technological Perspectives. Milan: Springer, p. 17-22.

Sander, T., Sloka, B. (2016). Motivators to Recommend Social Network Contacts to Employer. Regional Formation and Development Studies, No. 3 (20), p. 162-173. Klaipeda University.

Sander, T., Sloka, B., Paužuoliené, J. (2015). The Difference of Social Network Sites Explained with the Employment Seeking Process. Regional Formation and Development Studies, No. 3 (17), p. 145-154. Klaipėda University.

Siudikiené, D. (2013). Laisvalaikio medijų naudojimo ypatumai skirtingose Lietuvos auditorijos gyvenimo stilių grupèse. Informacijos mokslai, Nr. 66, p. 34-55. Vilniaus universitetas.

Siudikienè, D. (2014). Medijų auditorijų aktyvumo raiška daugiaterpejje medijų aplinkoje. Informacijos mokslai, Nr. 69, p. 43-58. Vilniaus universitetas.

Sowa, K. (2009). Gdy myślę uniwersytet... Krakow: Wydawnictwo Uniwersytetu Jagiellońskiego.

Stonkiené, M. (2014). Informacija internete apie Lietuvos aukštujų mokyklų studijų programas, teikiamas studijuoti naudojant informacijos ir ryšių technologijas. Informacijos mokslai, Nr. 69, p. 59-73. Vilniaus universitetas.

Wereda, W. (2009). Zarządzanie relacjami z klientem (CRM) a postępowanie nabywców na rynku ushug. Warszawa: Difin.

Yang, A., Alessandri, S. W., Kinsey, D. F. (2008). An Integrative Analysis of Reputation and Relational Quality: A Study of University-Student Relationships. Journal of Marketing for Higher Education, Vol. 18 (2), p. 145-170. 


\section{„FACEBOOKAS“, KAIP PRIEMONE VALDYTI STUDENT U TARPUSAVIO IR UNIVERSITETU SANTYKIUS LENKIJOJE BEI LIETUVOJE. BA N D OMU JU巳 TYRIMŲ REZULTATAI}

AgnieszKa SzczudlińsKa-Kanoś, Janusz Sasak, Ligita Šimanskienė

Jagielionijos universitetas (Lenkija), Klaipedos universitetas (Lietuva)

Santrauka

Šiomis dienomis, vykstant aktyviems socioekonominiams pokyčiams, ypač informacinių technologijų, žmonių bendravimo problema tampa vis svarbesnè ir sudètingesnè. Šiame straipsnyje siekiama išanalizuoti socialinių medijų vaidmenį, puoselëjant universitetų ir studentų tarpusavio santykius. Atliktas tyrimas. Tarptautinio bendradarbiavimo pastangomis sukurtas tyrimo įrankis ir bandomasis tyrimas, kuriame dalyvavo studentai iš atrinktų Lietuvos bei Lenkijos universitetų. Tyrimo rezultatai atskleide, kad „Facebookas“ yra akivaizdžiai pats populiariausias universitetuose bendravimo portalas tarp studentų. Jis labiausiai pripažịstamas kaip sparčios informacijos kaitos ir santykių puoselèjimo priemonè. Šie analizès rezultatai gali būti naudinga informacija ir universitetams, ir kitoms viešosioms įstaigoms, privačioms įmonèms, ypač socialinių tinklų operatoriams. Šiandien, tinkamas universiteto funkcionavimas neįsivaizduojamas be interneto, oficialaus tinklalapio ir socialinių tinklų profilių.

Remiantis tyrimų rezultatais, galima teigti, kad Lenkijos ir Lietuvos studentai daugiausia naudojasi „Facebooku“: net 95 \% studentų iš Lenkijos ir Lietuvos nurodo „Facebooką“ kaip pagrindinị socialinių ryšiu portalą. Jis iki šiol labiausiai vertinamas kaip pagrindine tiek sparčios informacijos sklaidos, tiek santykiu kūrimo priemonè. Kiti socialiniai tinklai, apie kuriuos klausta, nurodyti kaip veikiau informaciniai, kuriuose atrandama informacija tik papildo tą, kuri regima pagrindiniame bendravimo socialiniame tinkle „Facebook“. Ta papildoma informacija dažniausia pateikta paveiksliukais, medijų failais ar trumpomis žinutėmis, kurios skirtos pranešti apie problemą ar ją spręsti. Todèl aukštojo lavinimo institucijos, siekdamos valdyti santykius su studentais, turètų atsižvelgti ị socialinius pokyčius ir paplitusį elektroninių informacinių kanalų naudojimą, kartu ị studentų lūkesčius ir universiteto tradicijas, kai ypač svarbus studento asmeninis ryšys su kitu studentu. Situacija, kai visa santykių puoselèjimo atsakomybẻ tenka elektroninėms priemonėms, šị procesą lètina, kartu ir atpalaiduoja. Inertiškas tradicinių bendravimo būdų laikymasis ar netinkamas socialinių tinklų naudojimas gali lètinti procesus ir kelti jausmą, jog esama labai daug skirtingų veiklų, kartu nepasitenkinimą santykiais bei jų prastèjimą.

PAGRINDINIAI ŽODŽIAI: santykiu valdymas, universitetai, studentai, ,Facebookas “.

JEL KLASIFIKACIJA: M15

Received: 2017. 03.20

Reviesed: 2017.04.14

Accepted: 2017.04.20 